\title{
THE IDEOLOGICAL DIVIDES AND THE UPTAKE OF RESEARCH EVIDENCE THE CASE OF THE UNITED NATIONS WORLD POPULATION CONFERENCES ${ }^{1}$
}

\section{Dragana Avramov - Robert Cliquet}

\begin{abstract}
Population policies have been supported and considerably boosted by the activities of the United Nations, and in particularly by the UN Commission on Population and Development, the UN Population Division, and the United Nations Population fund (UNFPA). The authors document how the researcher community has presented a significant body of research evidence to world leaders in view of their policy deliberations and decision-making at the UN World Population Conferences in Bucharest in 1974, Mexico City in 1984 and Cairo in 1994.

The focus in this contribution on the last three 20th century population conferences is explained as follows. Scientific world population conferences in Rome 1954 and Belgrade 1965 were organised under the auspices of the UN as deliberation events. The Bucharest conference of 1974 was a turning point because it was a political event, in which representatives of 149 member states not only debated but also decided about the draft World Population Plan of Action (WPPA) in which principles and directives for population policy and action were formulated. The two following conferences followed along the same action oriented rationale.
\end{abstract}

\footnotetext{
1 This contribution builds on the methodology for impact review developed under the IMPACT_EV project funded by the European Commission under FP7 and is part of the study on Monitoring and evaluation tools in promoting European Research Area.
} 
The authors review policy achievements and missed opportunities of the three last world population forums from a scientific point of view by examining how research evidence was used for informing and transforming global population policies.

Keywords: population policy, world population conferences, demography, global data

Dargana Avramov

Director of Population and Social Policy Consultants (PSPC), Brussels; Former director of the Demographic Research Centre, Institute of Social Sciences, University of Belgrade.

E-mail:avramov@avramov.org

Robert Cliquet

Emeritus professor in anthropology and social biology of the Ghent University and honorary general director of the former Population and Family Study Centre (CBGS), Scientific Institute of the Flemish Community, Brussels, and PSPC advisor.

E-mail: avramov@avramov.org 


\section{INTRODUCTION}

This contribution looks at the UN world population conferences of 1974, 1984 and 1994 in a comparative perspective, and evaluate their achievements, missed opportunities, continuities and discontinuities of policy choices affecting world population developments. In particular, it takes into account the tensions existing between worldviews about population growth, development and the ecosystems in the developing and developed regions of the world.

There exists an extensive scientific literature about the United Nations' role and activities in the field of population, and in particular about its three major world population conferences. Most of those publications concern one of those conferences, Bucharest, Mexico City, or Cairo, ${ }^{2}$ while comparative contributions are rarer. ${ }^{3}$ Here, the purpose is not only to compare the shifts in focus of the three conferences, but also to view their policy recommendations in light of the contemporaneously available scientific knowledge about population and development.

The main sources of information for this contribution are:

- Key scientific literature on the past and expected world populationrelated developments in the 20th and 21st century (e.g. United Nations, 2015; Basten et al., 2013; Dodds, 2008; Ewing et al., 2010; Avramov, 1993).

- Scientific reports commissioned by the UN in preparation of the UN conferences of 1974, 1984 and 1994.

- Reports of the UN World Population Conferences (United Nations, 1975; 1984; 1994a).

- Publications by the authors on the UN World Population Conferences and population development (Cliquet and Veys, 1975; Cliquet and Van de Velde, 1984; Cliquet and Thienpont, 1994; 1995).

- Reports of the annual meetings of UN Population Committee/UN Committee on Population and Development related to the UN World Population Conferences (United Nations, 2004; 2014).

- The participation and involvement of one of the authors to the three UN World Population Conferences as scientific advisor to the Belgian governmental delegation at those conferences and several of their preparatory meetings.

\footnotetext{
2 For Bucharest see among others: Cliquet and Veys, 1974; Mauldin et al., 1974; Finkle and Crane, 1975. For Mexico see among others: Cliquet and Van de Velde, 1985; Brown, 1984; Wulf and Willson, 1984; Finkle and Crane, 1985. For Cairo see among others: Cliquet and Thienpont, 1995; Ashford, 1995; Johnson, 1995; Singh, 1998.

${ }^{3}$ For instance, Demeny, 1985; Finkle and McIntosh, 2002.
} 
- The experience of the authors as members of the UN Population Commission/Commission on Population and Development in the 1990s and other international fora.

We first highlight the main features of the $20^{\text {th }}$ century's unprecedented global population growth and its implications for the carrying capacity of the planet. We look at humans' ecological footprint, disparities in development and ambitions of both the developing and developed regions of the world.

Then, we briefly sketch the role of the United Nations bodies in addressing the world population question at the three UN world population conferences.

The body of the contribution consists of the comparison of the three conferences, first about their continuities and ruptures, and subsequently about their political achievements and difficulties in reconciling knowledge-based policy-making with worldviews embedded in ideologies.

The article is closed with some concluding reflections about the incorporation of research evidence for policy making as the ultimate measure of the impact of research in society.

\section{DEMOGRAPHIC CHALLENGES: THE PACE OF WORLD POPULATION GROWTH AND ITS CONSEQUENCES}

\section{The unprecedented world population growth in the $20^{\text {th }}$ century}

Rapid population growth is a distinguishing feature of the twentieth century and is expected to continue during this century. While the annual population growth rate in the period before the industrial cultural phase was very low and very slowly increased from $\square 0.04$ per cent in the hunter-gatherer era to 0.1-0.2 per cent in the ancient agrarian era, during the short span of modernising it very rapidly and strongly rose to just above two per cent in the period 1965-1970 (e.g. Hassan, 1975; Winterhalder et al., 1988; Gignoux et al., 2011; Zahid et al., 2016; United Nations Population Division, 2015). Since then, the pace of growth has decreased again and by the end of the $21^{\text {st }}$ century it is expected to be back at the very low values it had during most of human prehistory. The pace and rate of population growth thus represent a unique moment in the demographic history of humankind. It is pertinent to see how world leaders tackled this global challenge. 
The onset and the intensity of the difference between the decrease in mortality and fertility during the demographic transition caused an exponential growth of the human species, which evolved from about one billion people around 1800 to two billion around 1930, four billion around 1975 and six billion in 2000. According to the medium variant of the UN Population Division's Population Prospects the world population will, over the course of the $21^{15 t}$ century, further increase to about eleven billion by $2100^{4}$ (Figure 1).

The extremely strong increase of the world population since the second half of the $20^{\text {th }}$ century is mainly due to the remarkable decline in mortality and persistence of high fertility in the developing world as part of a modernisation processin which Europeanand North American populations havebeenforerunners. Between 1950 and 2000, 89 per cent of the world population increase was due to population growth in less developed regions; in the $21^{\text {st }}$ century, these regions were responsible for 98 per cent of global population growth. It is generally acknowledged that the pace of growth in many countries is a major challenge for the pace of socio-economic development and the ecological equilibria (e.g. Ehrlich et al., 1977; Wijkman and Rockström, 2012). There is less of an agreement whether less developed regions of the world need to achieve both mortality and fertility levels of the regions forerunners of demographic modernisation in order to enhance their socio-economic development.

\section{Population, development and environment}

The population in the more developed regions of the world accounts for 17 per cent of the world population but it is estimated that it uses or consumes 75 to 80 per cent of the Earth's resources, calculated per capita. In the developing world, those figures are reversed: the population of the less developed regions in the world accounts for 83 per cent of the world's population, but uses or consumes only 20 to 25 per cent of the Earth's resources, calculated per capita. ${ }^{5}$

\footnotetext{
${ }^{4}$ United Nations Population Division, 2015. https://esa.un.org/unpd/wpp/

${ }^{5}$ For the data see for instance, http://data.worldbank.org/indicator; Sustainable Europe Research Institute, 2009.
} 
Figure 1: World population prospects: the 2015 revision

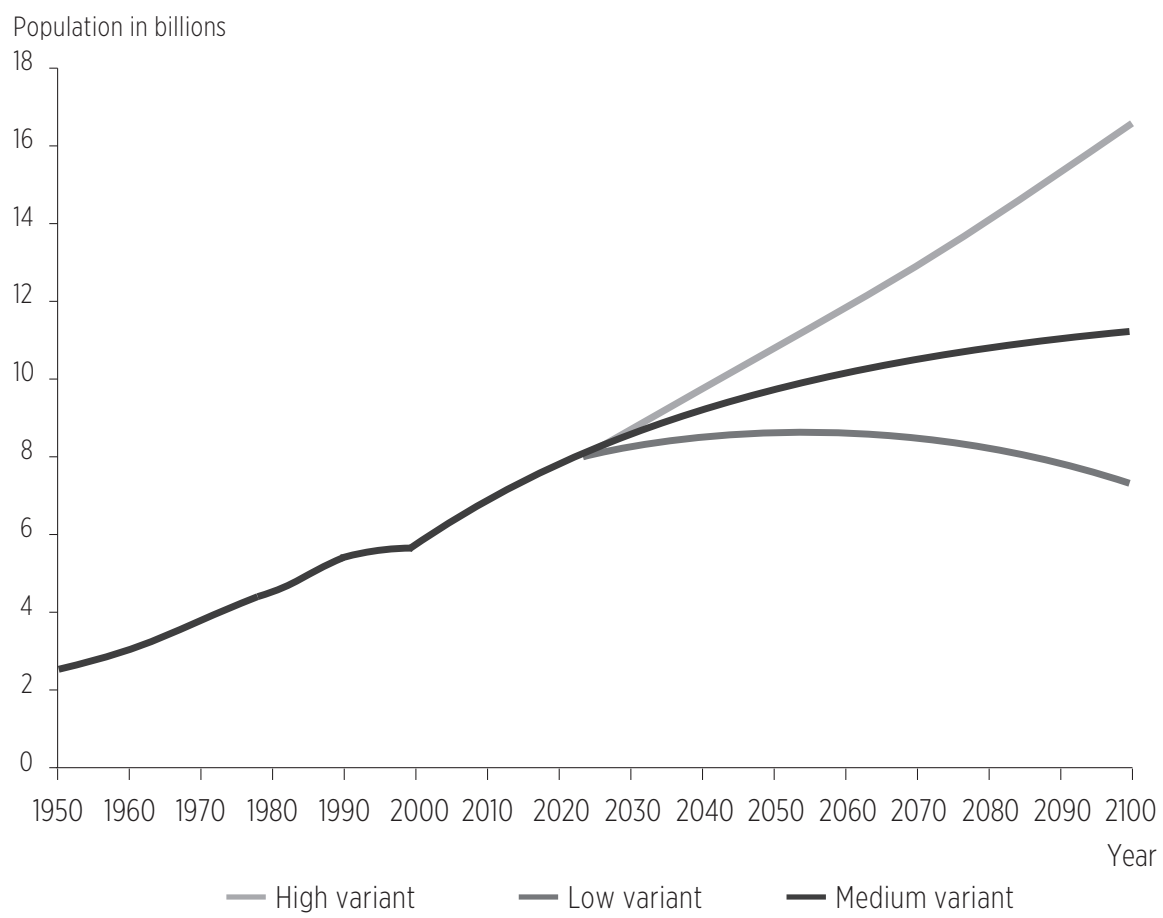

Source: United Nations Population Division, 2015.

On the basis of estimations of the Earth's Biocapacity $(\mathrm{BC})^{6}$ and the Ecological Footprint $(E F)^{7}$ of the human species, the Global Footprint Network ${ }^{8}$ calculated that, in 2007, the ecological overshoot (EF/BC) amounts to 50 per cent above unity, meaning that humanity uses already the equivalent of 1.5 Earths to support its consumption (Figure 2).

\footnotetext{
${ }^{6}$ Biocapacity $(\mathrm{BC})=$ area $\mathrm{x}$ bioproductivity (Ewing et al., 2010). The biocapacity is measured by calculating the amount of biologically productive land and sea area available to provide the resources a population consumes and to absorb its wastes, given current technology and management practices.

${ }^{7}$ Ecological footprint $(E F)=$ population $x$ consumption $x$ resource and waste intensity (Ewing et al., 2010). When the BC>EF, there is an ecological reserve; when the $\mathrm{BC}<\mathrm{EF}$, there is an ecological deficit. The ratio $\mathrm{EF} / \mathrm{BC}$ is the estimated ecological overshoot. In their Ecological Footprint Atlas 2010 edition, the Global Footprint Network estimated for 2007 the world's biocapacity at 11.9 billion global hectares (gha) and the ecological footprint at 18.0 billion global hectares (gha) for a world population of 6.7 billion people. This gives an average biocapacity per person of 1.8 global hectares (gha) and an average footprint per person of $2.7 \mathrm{global}$ hectares (gha), giving an ecological overshoot (EF/BC) of 1.5.

${ }^{8}$ Wackernagel and Rees, 1998; Ewing et al., 2010; http://www.footprintnetwork.org/.
} 
Figure 2: Biocapacity, Ecological Footprint and EF/BC ratio in 2007, per continent and world

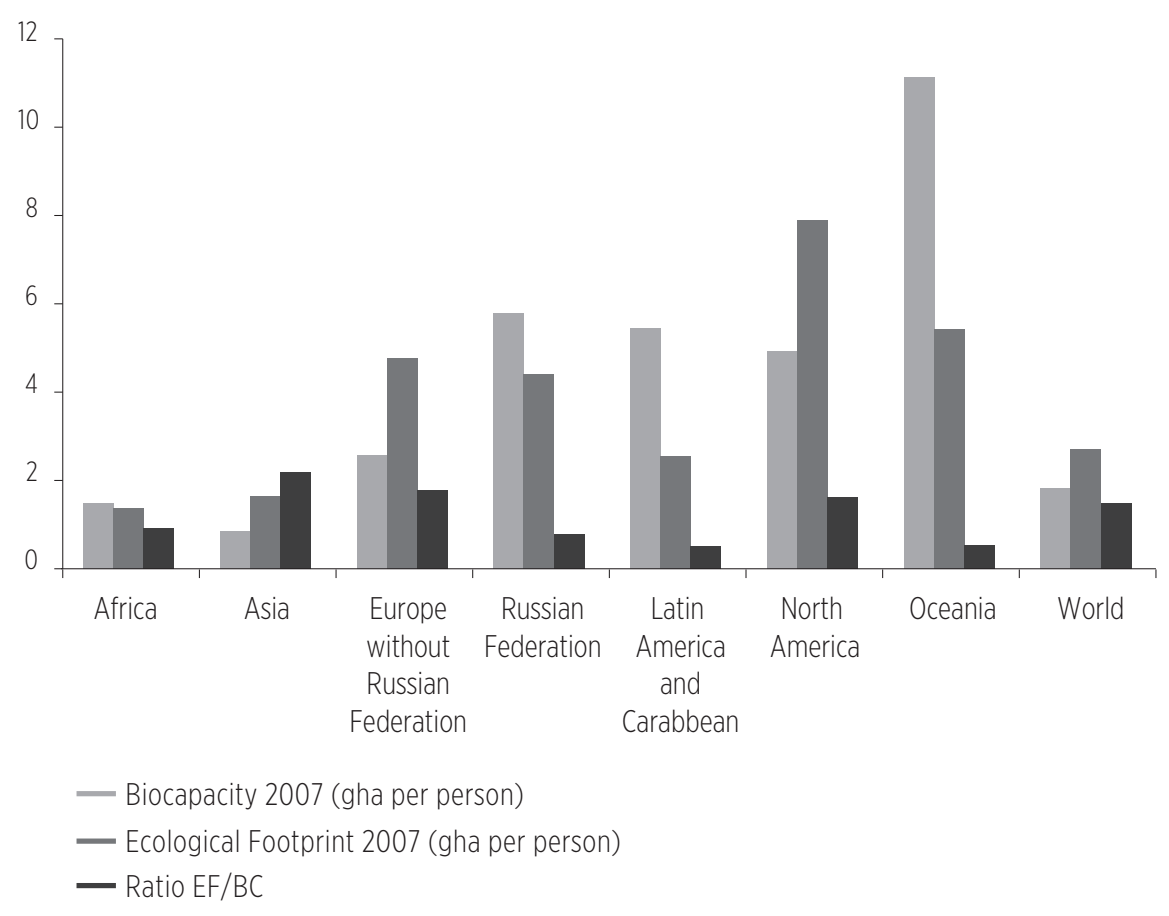

Source: authors' calculations based on Ewing et al., 2010.

Were the whole world to acquire the level of prosperity of Europe with its current consumption patterns by 2050, estimates suggest humanity would require almost four Earths. If the European consumption further increased linearly between 2007 and 2050, as it did between 1991 and 2007, and this level of consumption is applied to the whole world population in 2050, humanity would need nine Earths (Figure 3). ${ }^{9}$

The aspirations of the developing world (expressed in all UN world gatherings on development) are to reach the well-being levels of the developed world as soon as possible. The latter undoubtedly wants to further progress in the modernisation process, competitiveness, innovation and growth. Research points in the direction of the conclusion that the increase of the well-being of the human species as a whole can be achieved partly by changes in the

\footnotetext{
${ }^{9}$ Cliquet and Avramov, 2018, p.365; see also Wackernagel and Rees, 1998; Smail, 2002, p.28.
} 
consumption patterns, due to the limited nature of the Earth's resources, but also by the reduction of the world population size. In figure 4 we can see that there are countries which have a high Human Development Index in 2014 while they have relatively low ecological footprint a little bit earlier, so alternative developmental paths can be followed (Figure 4). UN world population conferences have drawn on and produced wealth of research evidence about the global challenges associated with needs to decrease the pace of growth of the world population.

Figure 3: Ecological deficit/reserve in 2007 and 2050, based on the hypothesis that the whole world acquires the level of prosperity and welfare of Europe with its current consumption patterns

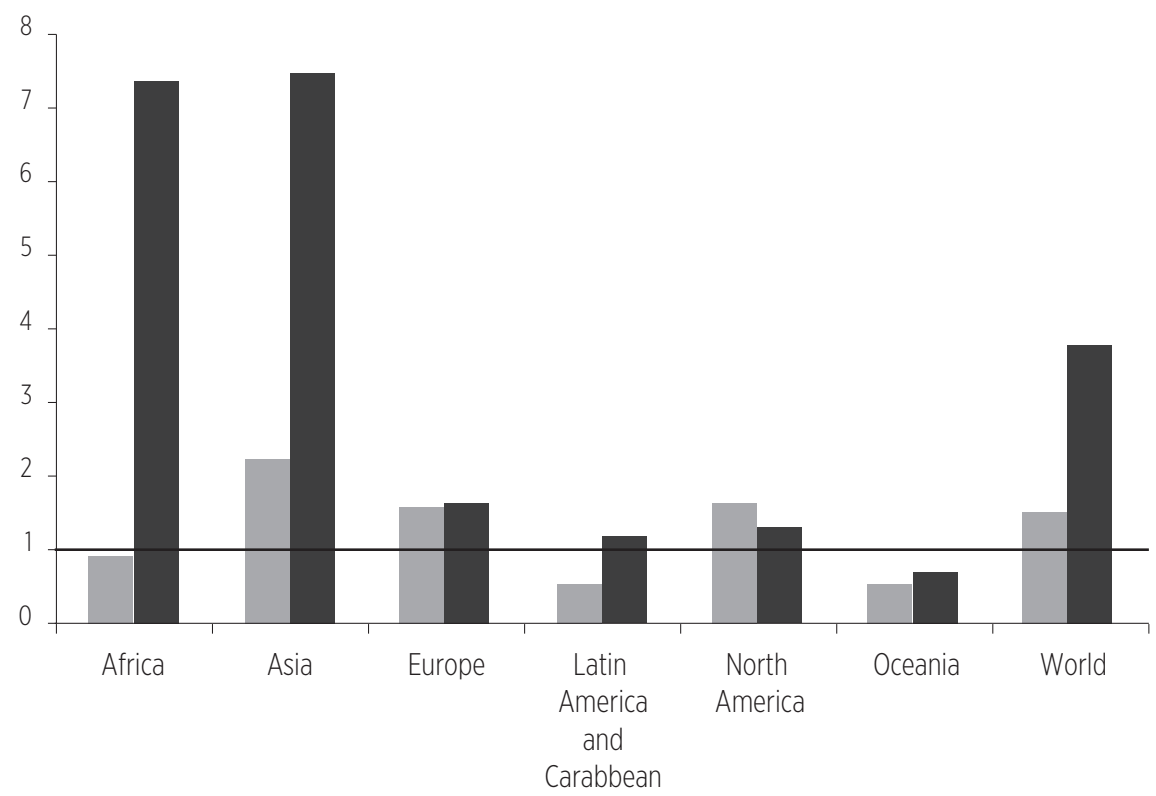

- Ratio EF/BC 2007 - Ratio EF/BC 2050

Source: authors' calculations on the basis of data from Ewing et al. 2010.

To assess the impact of this research evidence we will look at the policy recommendations of the UN world population conferences of 1974, 1981 and 1994 against the background of the current world demographic prospects and the developmental objectives and ambitions of both the developing and developed world as expressed at UN conferences. 
Figure 4: Relationship between Human Development Index (2014) and ecological footprint (2007) for 155 out of 188 countries in the world

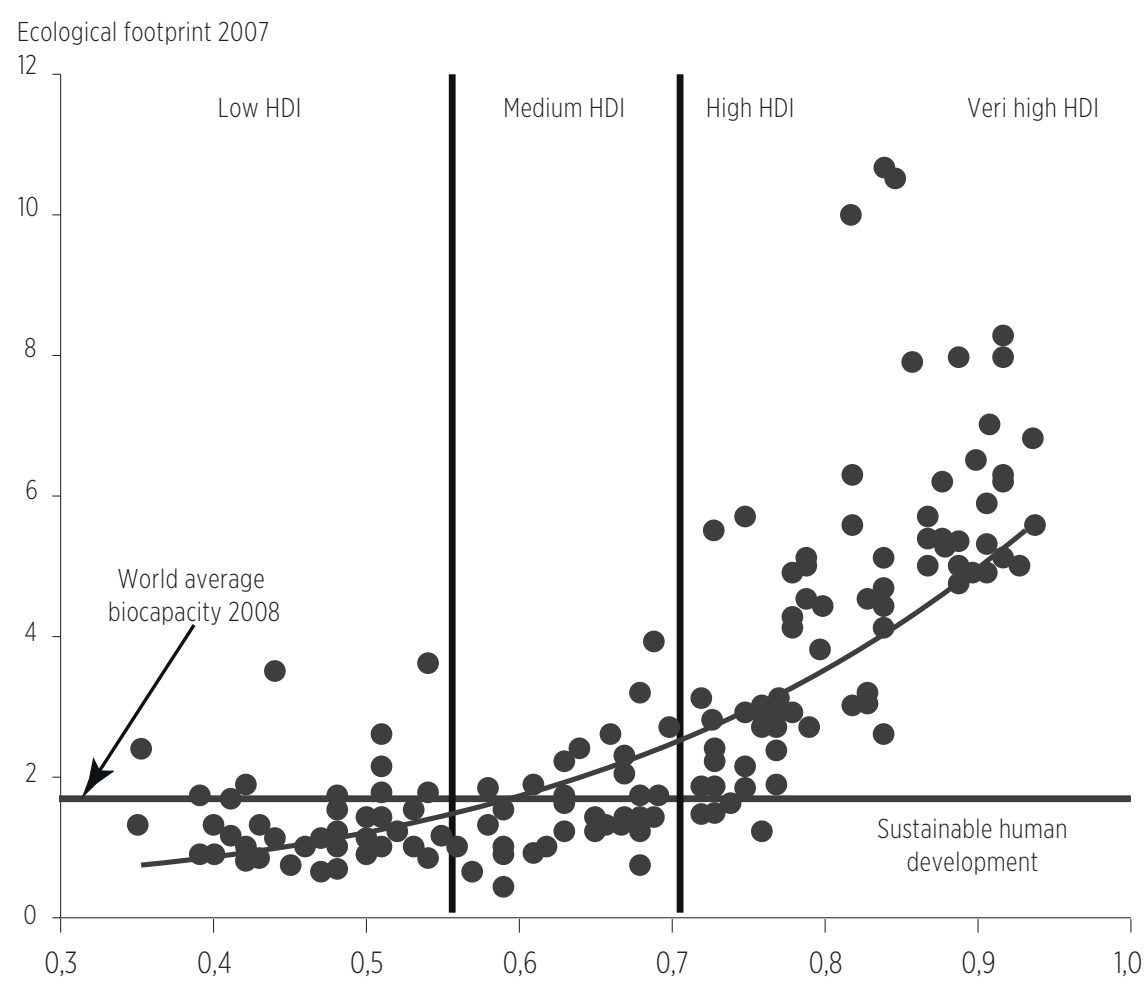

Source: after United Nations Development Programme, 2013.

\section{THE UNITED NATIONS AND THE WORLD POPULATION QUESTION}

The UN Population Commission

Almost immediately after the creation the United Nations (UN) in 1945 the organization started addressing the world population problem. In 1946, within the Economic and Social Council, it founded the Population Commission. In 1994, following the International Conference on Population and Development in Cairo, the Population Commission was renamed the Commission on Population and Development. 
The Commission meets annually and has the task of following the development of the world population, and to provide policy advice to the Economic and Social Council (ECOSOC).

Historically, the most important role of the Commission concerned the preparation of the major UN world population conferences in the last quarter of the twentieth century, namely, the 1974 UN World Population Conference in Bucharest (United Nations, 1975; Cliquet and Veys, 1974), the 1984 UN International Conference on Population in Mexico City (United Nations, 1984; Cliquet and Van de Velde, 1985), and the 1994 International Conference on Population and Development (ICPD) in Cairo (United Nations, 1994b; Cliquet and Thienpont, 1994; 1995; Johnson, 1995). The Commission's main task today is to follow up and evaluate the implementation of the UN ICPD Programme of Action adopted in Cairo.

\section{The United Nations Population Fund (UNFPA)}

UNFPA was founded in 1969 as an agency of the United Nations and aims to assist UN Member States in developing their policies on population issues (Salas, 1976; Sadik, 2010). During the course of its existence, the UNFPA acquired an increasingly important role within the organizational structure of the United Nations, partly because of its success in acquiring significant voluntary contributions and partly because of the size and quality of its activities in development (Mousky, 2002).

Originally, the official mission of the UNFPA, as determined by ECOSOC in 1973 and confirmed in 1993, strongly focused on population issues (Mousky, 2002; Robinson, 2010).

Since 1994 the action of the UNFPA is determined by the ICPD Programme of Action, widening its traditional goals from exclusively focusing on family planning objectives to also encompass those concerning sexual and reproductive health. This includes not only the promotion of contraceptive behaviour, but also prenatal and postnatal care, assisted childbirth and prevention of sexually transmitted diseases and HIV/AIDS. The selfdetermination - i.e. empowerment - of women is an important field of action, with particular attention going towards adolescents and young adults. Of course, traditional demographic concerns, such as population dynamics, including growth rates, age structure, fertility, mortality and migration, remain a permanent point of consideration. 
Since 2001, UNFPA's goals are co-determined by the Millennium Development Goals (MDGs) that resulted from the Millennium Summit of 2000. Because of this a further shift in emphasis took place towards general development targets. Although the Millennium Development Goals refer in Objective 3 ("Promoting gender equality and empowerment of women") to the ICPD Programme of Action and mention family planning several times in Objective 5 ("Improve maternal health"), it must be observed with great concern that the stabilization of the world population that was generally accepted by the three UN world conferences, is not included in the Millennium Development goals. Rightly, the All Party Parliamentary Group on Population, Development and Reproductive Health (APPG) of the UK highlighted this striking policy gap and pertinently argued that a ninth MDG should be added to this list (APPG, 2007). The absence of the stationary population target in the MDGs is another indication that population growth is still a goal among many policy makers, or that suggestions to curtail the world population growth or reduce its volume is perceived by some policy makers as controversial.

\section{THE UNITED NATIONS WORLD POPULATION CONFERENCES}

\section{The Bucharest Conference 1974}

The scientific World Population Conferences in Rome 1954 and Belgrade 1965 were organised under the auspices of the UN as deliberation events. The Bucharest conference of 1974 was a political event, in which representatives of 149 member states not only debated but also decided about the draft World Population Plan of Action (WPPA) in which principles and directives for population policy and action were formulated.

The conference was organised by the UNFPA, and several other UN agencies were involved, mainly the UN Population Committee of the UN Economic and Social Council, and the UN Population Division of the UN Secretariat.

The Bucharest Conference was preceded by the production of more than 100 scientific reports that were especially prepared for the conference, four important scientific symposia, five regional governmental consultative conferences, and an inquiry among governments on population and development (E/CONF.60/ $\mathrm{CBP} / 32,197)$. The scientific reports covered virtually all important issues that relate to world population development: recent population trends and future prospects in the world, population and socio-economic development, population 
and food supply, health trends and prospects and population and development, family, family planning, education, human rights, population policy, status of women, population assistance, resources and environment.10 Many of those documents provided an important input into the draft World Population Plan of Action (WPPA) prepared by the Conference Secretariat, working together with an experts' committee specially created for this purpose.

\section{The World Population Plan of Action in Bucharest 1974}

The WPPA contains a coherent set of principles, goals and recommendations concerning all important population issues and their relevance to economic and cultural development and the emancipation of human beings.

The plan is based on two fundamental principles:

1) All couples and individuals have the basic right to decide freely and responsibly the number and spacing of their children and to have the information, education and means to do so;

2) Population goals and policies are integral parts of social, economic and cultural development, whose principal aim is to improve the living conditions and the quality of life of all people.

Overall, the draft WPPA was largely in line with the scientific studies and reports from which it emanated. Nevertheless, the (draft) WPPA was evidently far from an ideal policy instrument. The drafting body tried to implicitly and explicitly accommodate some ideological and political sensitivities and prejudices. This was visible in the following examples:

- $\quad$ There were diverging approaches in quantitative objectives concerning mortality decrease and fertility decrease;

- There was a repeated emphasis on national sovereignty in population policy decision-making. National governments were not even invited to take into account the world population aspects;

- Topics such as contraceptive methods, sterilisation and induced abortion were not dealt with;

\footnotetext{
${ }^{10}$ On population trends: E/CONF/60/CBP/14, 1974; E/CONF/60/CBP/15, 1974; on population and food supply: E.CONF/60/ CBP/19, 1974; on health trends: E/CONF/60/CBP/26, 1974; on family: E/CONF/60/6, 1974; on family planning: E/CONF/60/ CBP/30, 1974; on education: E/CONF/60/20, 1974; on human rights: E/CONF/60/6; on population policy: E/CONF/60/21; on status of women: $\mathrm{E} / \mathrm{CONF} / 60 / 5$; on population assistance: $\mathrm{E} / \mathrm{CONF} / 60 / 24$; on resources and environment: $\mathrm{E} / \mathrm{CONF} / 60 / 5$, 1974.
} 
- Recommendations for containing further world population growth insufficiently reflected the urgency and gravity it deserved;

- The importance of issues concerning the relationship between population growth, consumption volumes and patterns, resource availability and ecological impairments were insufficiently dealt with;

- The disequilibria between population growth, socio-economic development and environmental disruption were insufficiently approached in a longer time perspective.

At the Bucharest conference the largely scientific approach of the preparatory bodies was initially strongly shadowed because of major ideological confrontations, which dominated and divided the world community at that time. Ideological standpoints were omnipresent in political narratives and reported in media. The divide was marked along:

1) 'Capitalist' versus 'communist' political worldviews: in the 1970s the confrontation between the proponents of a 'market-driven' economy and a 'centrally planned' economy still dominated the ideological and power schism in the world; this cleavage often was also presented as confrontation of pluralist 'free world' and one-party 'authoritarian' societies. This political/economic divide permeated the Bucharest discussions and negotiations. In the minds of many politicians in those days this cleavage was believed to be reflected also in the choice between 'family planning policy' and 'socio-economic policy'. The family planning propagation of some 'Western' agencies and NGOs had strongly fuelled a clear bias for family planning, while the primacy of the socio-economic development was strongly propagated by some communist countries, particularly the Soviet-Union, China, virtually all developing countries, and the Holy See. In reality, the discussions and negotiations at the conference were rather confusing, because, on the one hand, some of the communist delegations - e.g. China, Cuba - practiced, in addition to their socio-economic policy, a strong family planning policy; on the other hand, many delegations of the Western world strongly supported socio-economic developmental policies, in addition to family planning.

2) Ideological-religious versus scientific-secular approaches to population issues: the religious and culturally traditionalist position was strongly advanced by a very active and motivated Holy See. It opposed strongly family planning, in particular modern contraceptive methods, and calls to halt or reduce population growth. The Holy See also advocated 
traditionalist views on the family and the role of women. The positions of the Holy See were supported by a number of countries that were still strongly operating under Catholic Church hegemony.

3) Ideological or nationalistic expansionism versus global concerns formed another ideological cleavage in Bucharest: some governments still believed that population growth was a vehicle for increasing the national power position or economic wealth of the nation. This was the case for example for a number of South American and African countries that wanted their population to further grow. The nationalistic inspired demographic growth ideology was supported by an ideological mix of communist regimes, nationalist-expansionist or dictatorial regimes (e.g. several ultraright South American regimes and a few African countries), as well as by religiously motivated or dominated delegations; they all shared a belief in unlimited population growth ideology. On the other hand, many Western countries expressed concern about the global population growth and its implications for socio-economic and ecological development.

These three ideological/political narratives weighed heavily on the discussions and resulted in two major ethical/political divides concerning the approach and solution of the population challenges:

1) Disagreement about the direction of causality between socio-economic and demographic dynamics;

2) The opposition between the population growth ideology and the quests for population stationary.

Notwithstanding all of those obstacles, it was largely thanks to the persistent action of population scientists, members of delegations of mostly small European countries and some forward-looking developing countries, that the finally approved WWPA, albeit weakened or diluted, remained fairly consistent with the scientific studies from which it emanated. A major merit of the WPPA is that, in a world where policies were still strongly determined by ideological convictions, it was built largely, in its objectives as well in its recommendations, on scientific insights.

Some of the statements of national delegations, and in particular the reporting in mass media, suggested that the main dispute in the conference concerned the opposition between the position that socio-economic development is the best contraception versus the position stressing the importance of modern birth control, while neglecting developmental issues. Yet, in reality, no national 
delegation proposed strictly a family planning approach, and the draft WPPA included a well-balanced and integrated approach in which socio-economic, educational and demographic ('birth control') measures were interactively included.

\section{The International Conference on Population, Mexico City 1984}

In 1984, the UN convened a second intergovernmental world population conference in order to review and evaluate the WPPA and to adapt it in the light of the demographic and other developments that occurred since the Bucharest meeting and that were expected in the coming decades. This second UN world population conference was hosted by Mexico and was convened in Mexico City in August 1984 (United Nations, 1984).

The 1984 International Conference on Population (ICP) was also preceded by a substantial number of scientific studies, expert group meetings and regional preparatory conferences and consultations. These were aimed to fuel the draft recommendations to be prepared by the UN Population Division and amended and adopted by the UN Population Commission as preparatory committee (Prepcom) and finally by the ICP.

The expert group meetings concerned the following subjects: fertility and family; population distribution, migration and development; mortality and health policy; and population, resources, environment and development." For each of these expert group meetings, several basic preparatory research papers were commissioned and additionally a large number of other background documents were provided by specialised UN agencies and other international organisations (Cliquet and Van de Velde, 1985).

The ICP 1984 took advantage of the improvements in knowledge about population issues and their complex relations with socio-economic problems that resulted from the 1974 Bucharest conference and the subsequent increased activity of the UNFPA. Many developing countries became much more aware of their population problems and/or experienced the favourable effects of family planning policies.

Consequently, the attitudes at the ICP were quite different than at the onset of the Bucharest conference. Many developing countries approached the

\footnotetext{
"On fertility and family: E/CONF.76/PC/6, 1984; on migration and development: E/CONF.76/PC/7, 1984; on health and mortality: E/CONF.76/PC/9, 1984; on population and development: E/CONF.76/PC/8, 1984.
} 
population issues in a more knowledge-based and forward-looking way, the Soviet Bloc was much more restrained, China played a very cooperative role, the South Americans were more moderate in their traditionalism. Even the Holy See was not so vehemently opposing some degree of mastering of population growth.

To everybody's surprise, this time it was the United States that appeared the big ideological troublemaker, - a clear reversal in position compared to its diplomatic contribution to the Bucharest exercise. The Reagan administration suggested solving population problems by means of 'free enterprise' and introduced many amendments advocating that position. The stance of the US representatives was that the market would operate as an invisible hand bringing into balance population growth and economic development (Cliquet and Van de Velde, 1985; Finkle and Crane, 1985)

In addition, the conference was initially curbed and delayed in dealing with its specific mission by general discussions about issues of war and peace and the Israeli-Palestinian conflict despite the fact that there exist other, better equipped UN bodies for this mission.

It was again the scientific advisors of many small Western European countries, and Canada and Australia, and this time also some developing countries headed by women researchers or diplomats, strongly supported by the sagacious chair from Ghana12, who tried (and largely succeeded) to keep the draft recommendations of the Prepcom within scientifically sound borders.

\section{The Recommendations for the further implementation of the World Population Plan of Action}

The Mexico City recommendations largely confirmed the WPPA principles and action proposals. Regarding demographic trends, it was more objective and allinclusive than the Bucharest document.

The Mexico recommendations put more emphasis on the integration of population policies in general developmental policies, and highlighted the need to protect and restore ecological sustainability. However, despite the concern about the environment, there was still significant resistance to granting the environment issue priority status. Many developing countries insisted on a rational exploitation of resources, while developed countries were more

\footnotetext{
${ }^{12}$ All participants remember the chair's warning at the climax of one of the heated and confusing debates: "when the elephants fight, the grass suffers".
} 
concerned about environmental protection. At the conference, the populationenvironment relationship was considered a less-important issue than populationsocio-economic relationship.

Although the role and status of women was already present in the 1974 WPPA, the Mexico recommendations placed a stronger emphasis on the emancipation of women. This is probably the most striking, although insufficiently publicized break-through of the 1984 World Population Conference.

Nevertheless, just as in the Bucharest WPPA, the Mexico recommendations included a number of weaknesses or omissions which show that ideological or direct political drives continued to motivate many governments and prevented them from adequately considering global challenges.

This weakness appeared most clearly in the continued absence of quantitative targets and time lines regarding population growth and fertility levels. Moreover, the quite general recommendation dealing with population growth rates included so many built-in brakes - such as respect for ".... religious beliefs, philosophical convictions, cultural values and fundamental rights of each individual and couple" - that the message was opaque and lacked policy direction. The dimension of responsibilities of institutions and individuals was neither given sufficient attention in deliberations nor prominence in recommendations.

\section{The Mexico City Declaration on Population and Development}

The host country cherished the hope that the Conference would give rise to a 'Mexico City Declaration on Population and Development' (E/CONF.76/L.4,1984). However, the draft version turned out to be a vague, non-committal, poorly documented and badly structured paper. Fortunately an editing committee, composed of eminent population policy experts, succeeded in producing a plausible text, providing a coherent and clear overview of the whole range of international population problems and their relationship to socio-economic development and environmental challenges.

The Mexico Declaration clearly emphasized the urgency for addressing the demographic problems and provided a faithful account of the most crucial demographic developments in terms of growth, life expectancy, fertility and its regulation, population structure, urbanization and international migration. It highlighted the relationship between population and environment, as well as the connection between population and development and the resulting contrasts between developing and developed nations. The Declaration paid heed to 
the status of women and measures to empower women including freedom of reducing fertility. It called on the promotion of international cooperation in the spirit of universal solidarity and enlightened self-interest. It came as a surprise to many people that it was adopted without discussion in the Plenary of the Conference.

\section{The International Conference on Population and Development (ICPD), Cairo 1994}

Just as the two former UN conferences on population, the International Conference on Population and Development (ICPD) organised in Cairo in 1994 (United Nations 1994b) was preceded by an impressive and lengthy preparation, consisting, among others, of six expert group meetings, five United Nations regional conferences and, most importantly, three gatherings of the Preparatory Committee (Prepcom), consisting of the UN Population Commission and every UN member state that is not a member of the Population Commission.

The six expert group meetings concerned the following topics: Population, environment and development, population policies and programmes, population and women, family planning, health and family well-being, population growth and demographic structure, and population distribution and migration. ${ }^{13}$ They covered all major issues concerning the world population development and its relationship with major human, socio-economic and ecological challenges.

The Preparatory Committee met three times. At its first session in 1991, the Committee set the objectives of the meeting and defined the issues to be discussed. At its second Session in 1993, the Preparatory Committee agreed to establish a new programme of action to replace the WPPA and the Mexico recommendations to guide action on population in the next 20 years. However, no unanimous agreement on the one page table of contents was possible because Chapter $\vee$ bore the title 'The Family' instead of 'Families'. Namely, some Islamic countries insisted that there is only one type of family (i.e. a heterosexual married couple and their biological or adopted children), while other countries argued that there are different family types (e.g. non-married couples, re-constituted families, gay and lesbian families, etc.). At its third session, early in 1994, the

\footnotetext{
${ }^{13}$ For population and development: United Nations, 1994a; for population policies: United Nations, 1993; for population and women: United Nations, 1996b; for family planning and health: United Nations, 1996a; for population growth: United Nations, 1999; for international migration: United Nations, 1998.
} 
Preparatory Committee discussed the 'Draft Final Document: Programme of Action of the Conference' prepared by the ICPD Secretariat.

\section{The ICPD Programme of Action}

The text of the ICPD Programme of Action, approved in Cairo was completed in three phases:

1) The 'Draft final Document of the Conference' drawn up by the ICPD Secretariat;

2) The 'Draft Programme of Action' resulting from the Prepcom III negotiations;

3) The Programme of Action of the Conference', finalized and approved at the ICPD in Cairo.

As was the case for the two earlier UN world population documents, the preparation process, as well as the final outcome of the ICPD document, suffered from ideological prejudices and partisan ideological positions. This resulted, in many cases, in diluted or toned down principles or recommendations due to the UN practice of producing policy documents which can be accepted by consensus.

Major ideological oppositions, both at Prepcom III and the Cairo Conference, came mainly from the religious side, namely from some strongly doctrinarian Islamic states and the Holy See, supported by some Catholic countries. The religious versus secular conflict that emerged at the Cairo conference was sharper than during the previous conferences. The most disputed issues concerned:

- Opposition by the religious governments towards recognizing, in addition to religious values, a variety of other philosophical convictions or secular ethical values;

- Insistence on including in many sections, conditional formulations and references to full respect for cultural, traditional, or religious contexts or only approval of measures which are not impinging religious norms;

- Opposition to some recommendations relating to family diversity, sexual and reproductive rights and in particular abortion, gender equality and equity, and rights of adolescents.

For the sake of reaching a diplomatic consensus with the Holy See and some conservative Islamic countries, the dilution of the originally more scientifically based draft recommendations on subjects such as sexual and reproductive 
health, abortion, adolescents, and family diversity was accepted for the sake of reaching a diplomatic consensus. Nevertheless, even after successfully watering down recommendations, the same delegations ultimately remained uncompromising and expressed reservations as to their validity.

Just as in the former UN population conferences, ideologically motivated influences concerning quantitative population growth could also be discerned. The ICPD document recognized the need to achieve an "early stabilisation of the world population" or "sustainable development". However, it still did not include quantitative targets regarding population growth or size or fertility levels. It did, however, set some targets for access to effective and safe contraceptives, life expectancy, infant mortality, maternal mortality, education, and the necessary financial resources for the programmes concerning reproductive health care.

Also, the traditional emphasis on national sovereignty in population policy matters still persisted. The first sentence in the Chapter on Principles regarding the implementation of the recommendations contained in the ICPD Programme of Action, allowed governments to choose to ignore any or all specific recommendations.

A UN deliberation on a sensitive and complex problem, such as the relation between population and development in a world characterised by enormous inequalities between the more and less developed regions in the world, will inevitably confront discrepant interests, ideologies and goals for policy actions. For instance, this was visible in the different respective discourses of developing and developed countries on 'sustained economic growth' versus 'sustainable development'. The UN practice in such cases resulted in pasting together different types of concerns, which consequently allowed interpretations about policy directions to be left to the individual delegations.

Notwithstanding some differences in setting goals and ideological confrontations, the draft/final ICPD Programme of Action was in line with the WPPA. It included a number of innovations and specificities that could, from a scientific point of view, be evaluated very positively. The ICPD programme of action was largely built upon a scientific analysis of reality and strived to promote knowledge-based solutions:

- The 1994 ICPD Programme of Action was a much longer, more detailed and better elaborated document for all of the relevant demographic aspects than the 1974 WPPA; 
- It put a stronger and more extensive emphasis on environmental sustainability;

- It elaborated very extensively and pertinently on gender equality and equity and the empowerment of women;

- It broadened the goal of family planning to sexual and reproductive health and rights;

- It broadened the concept of development from its narrow economic perspective to the more comprehensive notion of quality of life of present and future generations (Van de Kaa, 1996).

Some authors believe that the ICPD arrived at an honourable settlement regarding the two main objectives in population policy, namely the macro approach, which is concerned with global growth and its adverse effects on development and environment (Wilmoth and Ball, 1992; Hodgson and Watkins, 1997), and the micro approach, which is concerned with the ability of individuals, particularly women, to decide freely about their reproductive behaviour (Lane, 1994; Mclntosh and Finkle, 1995; Sinding 2007; Robinson, 2010; Women's Declaration of the International Women's Health Coalition, 2012).

Our analysis of the discussions at the three world conferences in fact shows that the concern for macro and micro approaches was present at all three conferences, and was no innovation of the ICPD (Cliquet and Thienpont, 1994; 1995). ICPD did mark a significant step forward in the same direction, however.

Nonetheless, by systematically comparing most of the scientific literature with the recommendations of the ICPD Programme of Action, one is inevitably left with the feeling that the UN document did not consider adequately the misbalance between the population growth supported by some governments and the desire to generalise modern levels of quality of life for all populations.

A side effect of the ideology-driven debates at the Conference was that the opposition to curtailing the pace of population growth was disproportionately reported by the mass media. The impression was created that the ICPD Programme of Action mainly concerned marginally relevant demographic issues, such as abortion, promiscuity, or homosexuality, thus diverting the attention from the focal topics of the ICPD Programme of Action (i.e. the interrelationships between population growth, development and environment). 


\section{FROM BUCHAREST TO CAIRO: CONTINUITIES AND RUPTURES}

In the three UN world population conferences, we observe significant rifts on particular issues but, in our view, there was also significant continuity regarding efforts to use research knowledge for policy development.

More important than rifts between countries on single issues on which agreement could not be reached was, in our view, a divide between policymaking cultures.

\section{Confrontations, alliances and policy-making culture}

The three conferences were characterised by major changes in the narrative about differences that separate populations: the Bucharest conference was dominated by the then prevailing East-West ideological/political divide; the Mexico City conference faced a confrontation between the promotion of entrepreneurship to solve world challenges and comprehensive approaches to population policies; the Cairo conference was dominated by a sharpened antagonism between the religious and the secular worldviews.

Although all three world conferences were marked by religious opposition to family planning, the empowerment of women, and the slowdown of population growth, religious voices became more articulated and gained prominence in Cairo. The position of the Holy See advanced in Bucharest and Mexico was now reinforced as it blended with views of fundamentalist Islam countries, which states had become better organized as actors at the global level in the 1990s.

It may be argued that the world forum had numerous shortcomings. The world leaders could agree only on setting targets which had already been reached in the developed world. For the rest of the world, targets were either unrealistic or were not supported by adequate allocation of resources. Implementation of action plans occurred at variable geometry ${ }^{14}$. The narrative that the empowerment of women goes hand in hand with mastering of one's own fertility was too provocative for the traditionalists. They chose the narrative

\footnotetext{
14 'Variable-geometry' is the term used to describe the idea of a method that would enable groups of countries wishing to pursue a given goal to do so, while allowing those opposed to hold back. It is typically used in the European Union as "Variable-geometry" Europe. It may me used to describe the à la carte or cherry picking of UN standards and norms.
} 
of boundless population growth and infinite carrying capacity of the planet as a 'politically correct' worldview, which disguised their opposition to the 'politically incorrect' policy concerning the subjugation of women. The UNFPA motto 'Poor, powerless and pregnant' to describe the position of women in some parts of the world quickly fell into oblivion.

Nevertheless, a significant broadening of the perspectives took place between the three world conferences that contributed to changes in the policymaking culture. We can identify:

- An increasingly stronger emphasis on environmental concerns and promotion of the notion of sustainable development;

- A shift from a predominantly economic to a more holistic conception of development, expressed through the notion of quality-of-life;

- A shift from family planning to the broader concept of sexual and reproductive health rights;

- A stronger and more extensive focus on women's emancipation and empowerment.

Some experts have argued that the stronger elaboration of the empowerment of women and the broadening of fertility discourse to sexual and reproductive health was a sign of a move away from macro population concerns towards micro focus on individuals (e.g. Bashford, 2014). We do not share this assessment as the Cairo charter was built on good scientific arguments for developing layered and holistic policies encapsulating both macro and micro level actions.

There was some continuity in the power of ideologies in the policy-making culture that persisted throughout all three conferences. We observe continuities that weakened or toned down policy directions and recommendations due to:

- The faith-based and science-based confrontations about a number of sexual and reproductive issues regarding the empowerment of women and contraception, for example, that peaked at the Cairo conference;

- The belief of some governments that they could increase their weight and power position in the global world through population growth;

- The absolute primacy on national sovereignty principles in population matters over any of the global concern that prevailed at all three world conferences.

Notwithstanding the significant confrontations at the three UN population conferences, one is struck by the strong continuities regarding the value of the consensual processes and the cumulative effects of their positive results. 
A strong continuity is also observed in the use of research evidence for addressing demographic, socio-economic and ecological developments. The recommendations on these challenges show a striking continuity in the conference outputs: need for sustained attention to family planning, female emancipation, socio-economic progress in developing regions, environmental care and resource management.

\section{THE UN WORLD POPULATION CONFERENCES: POLICY ACHIEVEMENTS AND MISSED OPPORTUNITIES}

The UN population conferences and their outputs exhibit several policy achievements but also point to the missed opportunities with respect to the use of research evidence for achieving impact.

\section{Policy achievements}

The three UN population conferences have produced impressive researchbased population-related policy charters that include important principles and recommendations to guide policies at national and global levels.

Those conferences stressed the need to manage the strong population growth in the world, to enable people to plan effectively their family size, to socially and culturally emancipate and empower women, to achieve sustainability in the relations between population, economic development and environmental management, and to assist developing countries financially and logistically in achieving those goals.

Among the UN World Population Conferences, the 1974 Bucharest conference probably had the most significant impact on population policy. It contributed considerably to the dissemination of population knowledge in many developing countries, where policy makers often had little knowledge about the importance of rapid population growth and its effects on socio-economic and ecological development. In the wake of the 1974 conference, the UNFPA got the opportunity to considerably increase its activities in aiding and financing population policy programmes in many developing countries (Cliquet, 2012). As result, many developing countries initiated population-related policies. This was done in full awareness that such policies are no substitute for socio-economic policies, but that they do contribute to and interact positively with socio-economic and other 
welfare policies. Hence, the Bucharest conference can be considered to have been a crucial milestone and a highlight in the development of national and international population-related policies.

The 1984 Mexico City conference largely confirmed the established road map of the Bucharest conference, but with a much stronger emphasis on the needs for female emancipation and empowerment.

The 1994 Cairo conference elaborated all of the former conference goals in much greater detail, broadened some of the goals, and introduced a number of important new concepts in the population field, such as sexual and reproductive health, sustainable development, and quality-of-life.

Addressing population challenges as global issues and bringing them to the policy fore is a major policy impact of the research evidence (Avramov, 2017).

\section{Failures to achieve impact}

Their merits notwithstanding, the UN population policy charters included several gaps and shortcomings that weakened their power as knowledge-based moral and political standards:

- Prevalence of lopsided anthropocentrism in considering the relations between human demography, socio-economic development and environmental and resource sustainability;

- Hierarchical presentation of ethical and policy principles going from individual rights and state sovereignty, to global responsibilities. Absolute priority was given to individual rights without adequate consideration of natural resource availabilities, uses and overuses, and environmental abuses (climatic changes, air, water and soil pollution, decrease of biodiversity, destruction of natural ecosystems, etc.).

The key challenges were thus not coherently considered at the planetary level, transposed to the national level, and finally articulated through rights and responsibilities of individuals that would be placed in the global context;

- Emphasis of national sovereignty in population policy matters and lack of emphasis in national policies on global world;

- Omission of quantitative targets regarding fertility decrease;

- Omission or inadequate recommendations concerning sensitive issues, such as induced abortion and euthanasia;

- Although the issue of inadequate production and consumption patterns 
and use/abuse of natural resources is mentioned in the UN world population charters (more in particular in the ICPD Programme of Action), more particularly in the developed world, it is clearly insufficiently elaborated.

The UN population policy charters also included several weaknesses of a procedural nature that are inherent to the way in which the UN is organised and operates:

- The UN practice to weaken or dilute all policy documents in view of trying to reach a general consensus at any cost;

- The practice at UN population meetings to involve or broaden the demographic issues to everything, including economic issues, international power struggles (e.g. 'the US or Western supremacy'), and conflicts (e.g. 'the Israeli-Palestinian question');

- The UN practice of not taking into consideration the population question when addressing the environment (e.g. the 1992 United Nations Conference on Environment and Development in Rio de Janeiro, United Nations, 1992), development (e.g. 2010 UN Summit on the Millennium Development Goals, United Nations, 2000; 2011; 2015a.), or the climate (e.g. the 2015 United Nations Climate Change Conference in Paris, United Nations, 2015b);

- The presence of the Holy See as permanent observer state at population conferences where it does not act as state, but rather as representative of one religion. This created imbalance as other religions (e.g. Hinduism, Islam, Buddhism, etc.) and secular philosophical ideologies (e.g. International Humanistic and Ethical Union) did not have the same prerogative, resulting in an ideological-philosophical disequilibrium at such meetings. The specific status of the Holy See may have been inspirational for some Islamic theocracies (e.g. Iran, Sudan) which acted in the same religiondriven policy approach as the Holy See at the Cairo Conference;

- Although the UN population charters are largely based on scientific analyses of the population question and its relation to developmental and environmental concerns, ideological oppositions to the empowerment of women and turning a blind-eye to needs to curtail population growth, succeeded to weaken the impact of robust scientific knowledge.

The 2004 and 2014 reports of the UN Commission on Population and Development review and appraisal of the progress made in achieving the 
goals and objectives of the ICPD Programme of Action leaves the reader with very mixed feelings. On the one hand, the principles and recommendations of the ICPD are confirmed and much of the ICPD language is repeated. On the other hand, looking at some of the current demographic indicators of the UN Population Division and the UNFPA (UNFPA, 2016; , one is amazed by the salient absence in the Commission's reports of any reference to the persistent high population growth figures or still very high fertility levels in some of the world's most vulnerable regions. ${ }^{15}$ Also, a reflection about the longer-term world population growth and its relations with ecological challenges, climate change, and the developmental objectives and ambitions of both the developing and developed world is missing.

One of the outcomes of changes in the way population challenges are deliberated and acted upon is the inadequate and insufficient long-term consideration of lessons learnt through the World Population Conferences. In the Millennium socio-economic, educational and health goals there is a striking absence of consideration of the ecological and demographic implications of population growth. Both the population growth ideology and the individual/ family right to reproduce so strongly prevailed in many quarters that the need to decrease the population size to lower levels was never taken into consideration, let alone taken up as a valuable, honourable and adequate trajectory that could be pursued in the Millennium goals.

Yet, long-term demographic scenarios that build on below replacementfertility assumptions show that very small differences in average fertility can make a huge difference in the trajectory of the total world population and have significant implications for sustainability and quality-of-life. For example, with a sustained Total Fertility Rate (TFR) of 1.75 instead of 2.00 children per woman, the population on Earth by 2300 would only be three instead of eleven billion, i.e. eight billion less. If worldwide fertility decreased to the current average for Europe, the world population in 2300 would amount to approximately one billion (Figure 5). These scenarios are surely a valid basis for world deliberations about forward-looking policy choices.

\footnotetext{
${ }^{15}$ Total fertility rate lies on average above 3 children per woman in Arab States, above 4 in East- and South Africa, and above 5 in West- and Central Africa. Annual population growth rates are on average 2 per cent in Arab States (resulting in a doubling of the population in 35 years) and 2.7 per cent in East, West and South Africa (resulting in population doubling in 26 years).
} 
Figure 5: World population since the beginning of the nineteenth century, and its hypothetical future growth assuming low and medium variants of the total fertility rate (TFR: 1.50; 1.75; 2.00) and an average life expectancy of 90 years

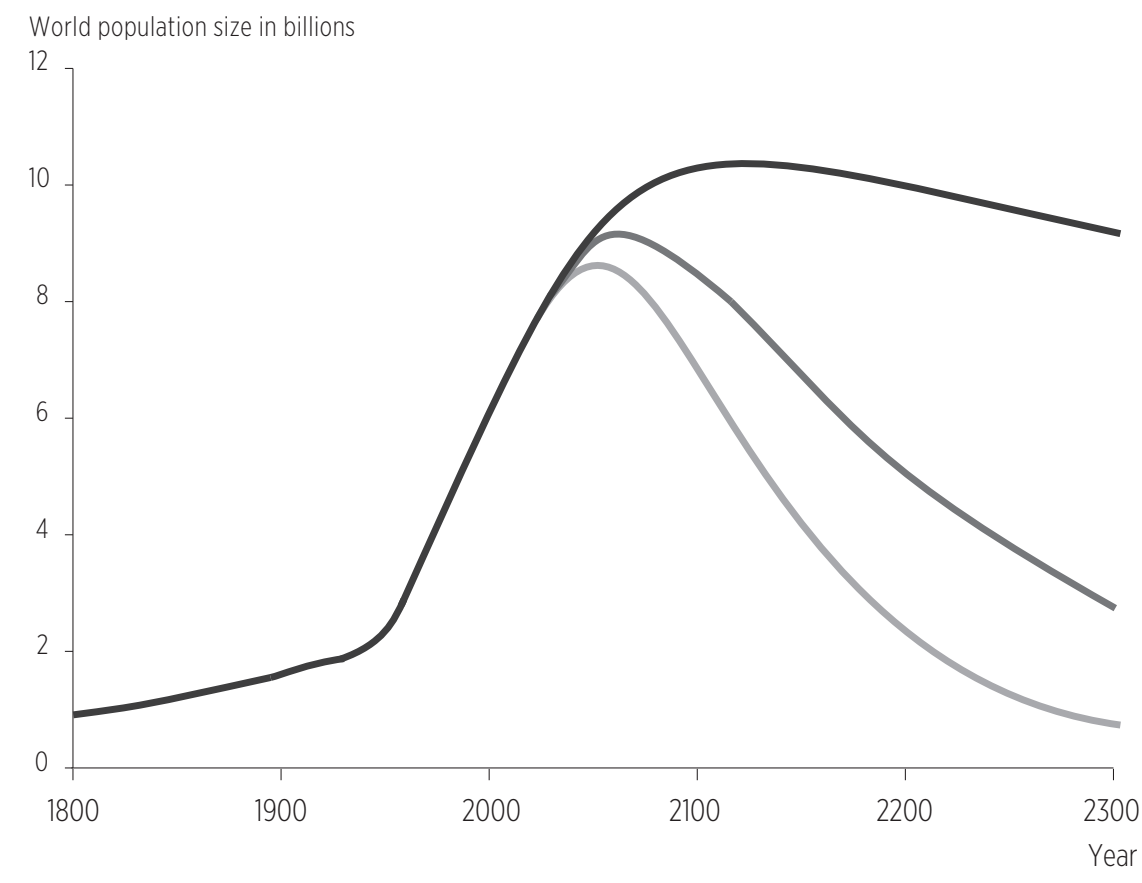

$$
\text { - TFR }=1,5 \quad \text { - TFR }=1,75 \quad-\text { TFR }=2,00
$$

Source: based on Basten, Lutz, and Scherbov, 2013; see also United Nations Population Division, 2004. 


\section{CONCLUDING REFLECTIONS}

The population policy charters that resulting from the UN World Population Conferences of 1974, 1984 and 1994 are undoubtedly important documents that contributed strongly to increase the knowledge and awareness of global population issues and challenges. They stimulated, or even initiated, the development of population policy initiatives and action programmes in many developing countries.

Despite evidence of the value of world population deliberations and of action plans to support policy choices, the World Population Conference as a global forum was disbanded. There has been no post-Cairo global population forum.

The reasons for disbanding of world population conferences as a deliberation and policy platform may be summarized as follows. Anthropocentric population growth ideology is resilient. The achievements of the World Population Conferences for promoting knowledge-based policies are insufficiently known to the lay people and insufficiently valorised in the research community. Developed countries are not willing to financially support the organization of deliberations at a world event as shifts have occurred in the world order and in the political weight of secular worldviews since the 1994 Cairo conference. Greater prominence on the world stage has been acquired through alliances of governments supporting religious norms about fertility and population growth and there are risks that a new deliberation would likely result in watering down of action plans build over past decades. 


\section{REFERENCES}

APPG (2007). Return of the Population Growth Factor. Its Impact upon the Millennium Development Goals. Report of Hearings by the All Party Parliamentary Group on Population, Development and Reproductive Health. London.

Ashford, L.S. (1995). New perspectives on population: lessons from Cairo. Population Bulletin, 50 (1), pp.1-44.

Avramov, D. (1993). Pojedinac, porodica i stanovnistvo u raskoraku (Individual, family and population in mismatch). Naucna knjiga, Beograd

Avramov, D. (2017). Monitoring and evaluation tools in promoting European Research Area, IMPACT-EV (forthcoming)

Bashford, A. (2014). Global Population: History, Geopolitics, and Life on Earth. Columbia Studies in International and Global History. Columbia University Press, New York.

Basten, S., Lutz, W. and Scherbov, S. (2013). Very Long Range Global Population Scenarios to 2300 and the Implications of Sustained Low Fertility. Demographic Research, 28 (39), pp.1145-1166.

Brown, G.F. (1984). United Nations International Conference on Population, Mexico City, 6-13 August 1984. Studies in Family Planning, 15 (6), pp.296-302.

Cliquet, R. (2010). Biosocial Interactions in Modernisation. Masaryk University Press, Brno.

Cliquet, R. (2012). Het Bevolkingsfonds van de Verenigde Naties (UNFPA). [The population fund of the United Nations]. In: C. Ryngaert, ed., De Fondsen en Programma's van de Verenigde Naties. Acco, Leuven.

Cliquet, R. and Avramov, D. (2018). Evolution Science and Ethics in the Third Millennium. Challenges and Choices for Humankind. Springer, Cham.

Cliquet, R. and Veys, D. (1974). Naar een wereldbevolkingspolitiek? De Wereldbevolkings-conferentie in Boekarest, 19/30 augustus 1974. [Towards a world population policy? The World Population Conference in Bucharest]. Studies en Documenten 4. De Nederlandsche Boekhandel/De Sikkel, Kapellen.

Cliquet, R. and Thienpont, K. (1994). Bevolking en duurzaamheid. Een uitdaging voor de 27ste eeuw. Resultaten van de Internationale Conferentie over Bevolking en Ontwikkeling, Kaïro, 5-13 september, 1994. [Population and sustainability. A challenge for the $21^{\text {st }}$ century. Results of the International Conference on Population and Development, Cairo, 5-13 September 1994]. CBGS-Monografie, 1994/2. Centrum voor Bevolkings- en Gezinsstudie, Brussel.

Cliquet, R. and Thienpont, K. (1995). Population and Sustainability. The Message from the Cairo Conference. European Studies of Population, Volume 3. Kluwer Academic Publishers, Dordrecht, Boston, London.

Cliquet, R. and Van de Velde, L. (1985). De Wereldbevolking op een Keerpunt? Resultaten van de Internationale Bevolkingsconferentie, Mexico, 6-14 augustus 1984. [The World population at a turning point? Results of the International Conference on Population, Mexico, 6-14 August 1984] C.B.G.S. Monografie 1985/3. Centrum voor Bevolkings- en Gezinstudie, Brussel. 
Demeny, P. (1985). Bucharest, Mexico City, and beyond. European Journal of Population, 1. pp.131-139.

Dodds, W.K. (2008). Humanity's footprint: Momentum, impact, and our global environment. New York: Columbia University Press.

E/CONF/60/4 (1974). Population Change and Economic and Social Development. ICP conference document. New York: United Nations.

E/CONF/60/5 (1974). Population, Resources and Environment. New York: United Nations.

E/CONF/60/CBP/5 (1974). Women's Rights and Fertility. New York: United Nations Secretariat.

E/CONF/60/6 (1974). Population and the Family. New York: United Nations.

E/CONF/60/CBP/6 (1974). United Nations Standards Concerning the Relationship Between Human Rights and Various Population Questions. New York: United Nations.

E/CONF/60/CBP/14 (1974). Demographic Trends in the World and its Major Regions, 1950-1970. New York: United Nations Secretariat.

E/CONF/60/CBP/15 (1974). World and Regional Population Prospects. New York: United Nations Secretariat.

E.CONF/60/CBP/19 (1974). World Population and Food Supply: Looking Ahead. New York: United Nations.

E/CONF/60/CPB/20 (1974), Population and Education. Paris: UNESCO.

E/CONF/60/CBP/21 (1974). Population Policies and Programmes. New York: United Nations Secretariat.

E/CONF/60/CBP/24 (1974). The Role of International Assistance in the Population Fields. New York: UNFPA.

E/CONF/60/CBP/26 (1974). Health Trends and Prospects in Relation to Population and Development. Geneva: WHO.

E/CONF/60/CBP/30 (1974). Health and Family Planning. Geneva: WHO.

E/CONF.76/L.4 (1984). Mexico City Declaration on Population and Development Adopted by the International Conference on Population, Mexico City, 14 August 1984. New York: United Nations.

E/CONF.76/PC/6 (1984). Recommendations of the Expert Group on Fertility and Family. New York: United Nations.

E/CONF.76/PC/7 (1984). Recommendations of the Expert Group on Population Distribution, Migration and Development. New York: United Nations.

E/CONF.76/PC/8 (1984). Recommendations of The Expert Group on Population, Resources, Environment and Development. New York: United Nations.

E/CONF.76/PC/9 (1984). Recommendations of the Expert Group on Mortality and Health Policy. New York: United Nations.

Ehrlich, P., Ehrlich, A. and Holdren, J.P. (1977). Ecoscience. Population, Resources, Environment. San Francisco: Freeman and Co.

Ewing, B., Moore, D., Goldfinger, S., Oursler, A., Reed, A. and Wackernagel, M. (2010). Ecological Footprint Atlas 2010. Oakland: Global Footprint Network. 
Finkle, J.L. and Crane, B.B. (1975). The Politics of Bucharest: Population, Development, and the New International Economic Order. Population and Development Review, 1(1), pp.87-114.

Finkle, J.L. and Crane, B.B. (1985). Ideology and Politics at Mexico City: The United States at the 1984 International Conference on Population. Population and Development Review, 11 (1), pp.1-28.

Finkle, J.L. and McIntosh, C.A. (2002). United Nations Population Conferences: Shaping the Policy Agenda for the Twenty-First Century. Studies in Family Planning, 33, pp.11-23.

Gignoux, C.R., Henn, B.M. and Mountain, J.L. (2011). Rapid, global demographic expansion after the origins of agriculture. PNAS, 108, pp.6044-6049.

Hassan, F.A. (1975). Determination of the size, density, and growth rate of hunting-gathering populations. In: Polgar, S. ed., Population, Ecology and Social Evolution. The Hague: Mouton. pp.27-78.

Hodgson, D., and Watkins, S.C. (1997). Feminists and Neo-Malthusians: Past and Present Alliances. Population and Development Review, 23, pp.469-523.

International Women's Health Coalition (2012). www.IWHC. org.

Johnson, S. (1995). The Politics of Population: The International Conference on Population and Development. London: Earthscan.

Lane, S.D. (1994). From Population Control to Reproductive Health: An Emerging Policy Agenda. Social Science \& Medicine, 39: 1303-1314.

Mauldin, W.P., Choucri, N., Notestein, F.W. and Teitelbaum, M. (1974). A report on Bucharest. The World Population Conference and the Population Tribune, August 1974. Studies in Family Planning, 5 (12), pp.357-395.

Mclntosh, C.A. and Finkle, M. (1995). The Cairo Conference on Population and Development: A New Paradigm? Population and Development Review, 21, pp.223-260.

Mousky, S. (2002). UNFPA's Role in the Population Field. In: Sadik, N. ed., An Agenda for People: The UNFPA Through Three Decades. New York: NYU Press. pp.211-247.

Robinson, R.S. (2010). UNFPA in Context: An Institutional History. Background paper prepared for the Center for Global Development Working Group on UNFPA's Leaderships Transition. School of International Service. American University.

Robinson, W.C., and Ross, J.A. eds. (2007). The Global Family Planning Revolution: Three Decades of Population Policies and Programs. Washington DC: World Bank. <https://www.cgdev.org/doc/UNFPA-in-Context.pdf>

Sadik, N. (2002). An Agenda for People: The UNFPA Through Three Decades. New York: NYU Press.

Salas, R.M. (1976). People: An International Choice: The Multilateral Approach to Population. Oxford: Pergamon Press.

Sinding, S.W. (2007). Overview and Perspective. In: W.C. Robinson, and Ross, J.A. eds. (2009). The Global Family Planning Revolution. Washington: The World Bank. pp.1-12. 
Singh, J.S. (1998). Creating a New Consensus on Population: The International Conference On Population and Development. London: Earthscan.

UNFPA (2016). The State of the World Population 2016. UNFPA, New York NY.

United Nations (1975). Report on the United Nations World Population Conference, 1974, Bucharest 19-30 August 1974. New York: United Nations.

United Nations (1984). Report on the United Nations International Conference on Population, 1984, Mexico City, 6-14 August 1984. New York: United Nations.

United Nations (1992). United Nations Conference on Environment \& Development Rio de Janerio, Brazil, 3 to 14 June 1992. AGENDA 21. New York: United Nations.

United Nations (1993). Population Policies and Programmes. Proceedings of the United Nations Expert Group Meeting on Population Policies and Programmes, Cairo, Egypt, 12-16 April 1992. New York: United Nations.

United Nations (1994a). Population, Environment and Development: Proceedings of the United Nations Expert Group on Population, Environment and Development, United Nations Headquarters, 20-24 January 1992. New York: United Nations.

United Nations (1994b). Report on the International Conference on Population and Development, Cairo: 5-13 September, 1994. Sales No. E. 95.XIII.18. New York: United Nations.

United Nations (1996a). Family Planning, Health and Family Well-Being: Proceedings, United Nations Expert Group Meeting on Family Planning, Health and Family Well-Being, Bangalore, India, 1992. United Nations, New York NY.

United Nations (1996b). Population and Women: Proceedings of the United Nations Expert Group Meeting on Population and Women, Gaborone, Botswana, 22-26 June 1992. United Nations, New York NY.

United Nations (1998). Population Distribution and Migration: Proceedings of the United Nations Expert Group Meeting on Population Distribution and Migration, Santa Cruz, Bolivia, 18-22 January 1993. New York: United Nations.

United Nations (1999). Population Growth and Demographic Structure. Proceedings of the United Nations Expert Group Meeting on Population Growth and Demographic Structure, Paris, 16-20 November 1992. New York: United Nations.

United Nations (2000). United Nations Millennium Declaration. 55/2. United Nations General Assembly. New York: United Nations.

United Nations (2004). Commission on Population and Development Report on the thirty-seventh session (22-26 March and 6 May 2004). E/2004/25 E/ CN.9/2004/9. New York: United Nations.

United Nations (2011). The Millennium Development Goals Report 2011. New York: United Nations.

United Nations (2014). Commission on Population and Development Report on the Forty-seventh Session (26 April 2013 and 7-11 April 2014). E/2014/25-E/

CN.9/2014/7. New York: United Nations. 
United Nations (2015a), United Nations Sustainable Development Summit 2015, 25-27 September 2015. New York: United Nations.

United Nations (2015b). Framework Convention on Climate Change: Paris Agreement 2015. New York: United Nations.

United Nations Development Programme (2013). Human Development Report 2013 The Rise of the South: Human Progress in a Diverse World. New York: UNDP.

United Nations Population Division (2004). World Population 2300. New York: United Nations.

United Nations Population Division (2015). World population prospects. The 2015 revision. New York: United Nations.

Van de Kaa, D.J. (1996). The Cairo Conference: a demographer's view. In: H. Van den Brekel and F. Deven eds. (1996). Population and Family in the Low Countries 1995: Selected Issues. Dordrecht: Springer.

Wackernagel, M. and Rees, W. (1998). Our Ecological Footprint: Reducing Human Impact on the Earth. Gabriola Island, Canada: New Society Publishers.

Wijkman A. and Rockström, J. (2012). Bankrupting Nature. Denying our Planetary Boundaries. A Report to the Club of Rome. London: Routledge.

Wilmoth, J.R. and Ball, P. (1992). The Population Debate in American Popular Magazines, 1946-1990. Population and Development Review, 18. pp.631-668.

Winterhalder, B.W., Baillargeon, F., Cappelleto, R., Daniel, R. and Prescott, C. (1988). The population dynamics of hunter-gatherers and their prey. Journal of Anthropology and Archaeology, 7, pp.289-328.

Wulf, D. and Willson, P.D. (1984). Global Politics in Mexico City. Family Planning Perspectives, 16(5), pp.228-232.

Zahid, H.J., E. Robinson, R.L. Kelly (2016). Agriculture, population growth, and statistical analysis of the radiocarbon record. PNAS, 113(4), pp.931-935. 